

\section{ReVIews Editor \\ Claire Nesbitt \\ Associate Editor \\ Rebecca Gowland \\ Editorial Assistant \\ Ross Kendall}

\section{Editorial Manager \\ Liz Ryan}

Deputy Editorial Manager

Thomas Swindells

\author{
Editorial AdDress \\ Antiquity, Department of Archaeology, \\ Durham University, South Road, Durham DH1 3LE, UK \\ Tel: +44 (0) 191 3341125; Email: editor@antiquity.ac.uk
}

Antiquity is an international, peer-reviewed journal of archaeological research that aims to communicate the most significant discoveries, theory, method and cultural resource issues rapidly and in plain language to practising archaeologists everywhere.

Antiquity is included in the Cambridge Journals Online service at http://journals.cambridge.org/AQY. Additional and freeto-access material may be found at http://antiquity.ac.uk

Antiquity was founded in 1927 by O.G.S. Crawford and is owned by the Antiquity Trust, a registered charity. The trustees of the Antiquity Trust are Graeme Barker, Amy Bogaard, Robin Coningham, Barry Cunliffe, Roberta Gilchrist, Anthony Harding, Martin Millett, Nicky Milner, Stephanie Moser and Cameron Petrie.

The Directors of Antiquity Publications Ltd, owned by the Antiquity Trust and responsible for producing Antiquity are Chris Gosden, Sue Hamilton, Nicky Milner, Cameron Petrie, Mike Pitts, Marie Louise Stig Sørensen and Robert Witcher.

\title{
Editorial AdVIsory Board
}

Peter Bellwood, The Australian National University, Australia Peter Mitchell, University of Oxford, UK

Xingcan Chen, Chinese Academy of Social Sciences, Beijing Timothy Pauketat, University of Illinois, USA

Eduardo Goés Neves, Universidade de São Paulo, Brazil Victor Paz, University of The Philippines, The Philippines

Elizabeth Graham, University College London, UK Michael Petraglia, Max Planck Institute for the Science of

Charles Higham, University of Otago, New Zealand Human History, Jena, Germany

Corinne Hofman, Leiden University, the Netherlands Innocent Pikirayi, University of Pretoria, South Africa

Stephen Houston, Brown University, USA Susan Pollock, Freie Universität Berlin, Germany

Timothy Insoll, University of Exeter, UK Natalia Shishlina, State Historical Museum, Moscow, Russia

Susan Keech McIntosh, Rice University, USA Benjamin Smith, University of Western Australia, Australia

Ian Kuijt, University of Notre Dame, USA Claire Smith, Flinders University, Australia

Kevin Lane, Universidad de Buenos Aires, Argentina Monica Smith, University of California, Los Angeles, USA

Akira Matsuda, University of Tokyo, Japan Miriam Stark, University of Hawai i-Manoa, USA

Barbara Mills, University of Arizona, USA Sarah Tarlow, University of Leicester, UK

Antiquity is published six times a year by Cambridge University Press for Antiquity Publications Ltd: February, April, June, August, October, December.

Advertising enquiries to the publisher at advertising@cambridge.org

CAntiquity Publications 2019. All rights reserved. No part of this publication may be reproduced, in any form or by any means, electronic, photocopying or otherwise, without permission in writing from Cambridge University Press. Permission to copy (for users in the USA) is available from Copyright Clearance Center, http://www.copyright.com, email: info@copyright.com.

This journal issue has been printed on FSCTM-certified paper and cover board. FSC is an independent, non-governmental, not-for-profit organisation established to promote the responsible management of the world's forests. Please see www.fsc.org for information.

Printed by Bell \& Bain Limited, Glasgow, UK.

Design: Barry Perks (www.yo-yo.uk.com)

Typesetting: Nova Techset Private Limited, Bengaluru \& Chennai, India.

Subscriptions can be purchased from Cambridge University Press and online at https://www.cambridge.org/core/journals/ antiquity/subscribe

Front cover: Limestone wall inside Manitou Cave, Alabama, USA, where historical and modern tourist graffiti cover the lower, eye-level sections of wall, while early nineteenth-century Cherokee syllabary inscriptions reflecting religious communications are positioned high on the ceiling above. Cherokee scholars Beau Duke Carroll (an archaeologist from the Eastern Band of Cherokee Indians) and Julie Reed (an historian from the Cherokee Nation of Oklahoma) are shown examining the various inscriptions (photograph by A. Cressler). For further details, see the full article by Carroll et al. in this issue. 


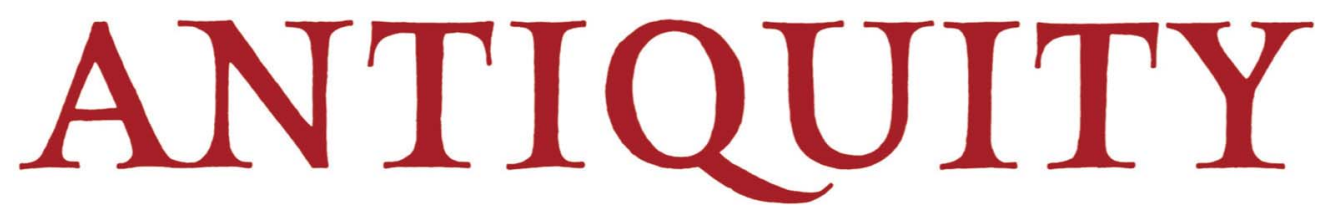

Volume $93 \quad$ Number 368

April 2019

\section{Editorial}

289

Robert Witcher

\section{Research}

Expanding the horizons of Palaeolithic rock art: the site of Romualdova Pećina

Aitor Ruiz-Redondo, Darko Komšo, Diego Garate Maidagan, Oscar Moro-

Abadía, Manuel Ramón González-Morales, Jacques Jaubert \& Ivor Karavanić

Nine-thousand years of optimal toolstone selection through the North

American Holocene

Jeremy C. Williams, Diana M. Simone, Briggs Buchanan, Matthew T.

Boulanger, Michelle R. Bebber \& Metin I. Eren

Prosperity and complexity without farming: the South China Coast, $c .5000$ $3000 \mathrm{BC}$

Hsiao-chun Hung

A well-preserved Michelsberg Culture domed oven from Kortrijk, Belgium

Dimitri Teetaert, Nathalie Baeyens, Yves Perdaen, Géraldine Fiers, Tim De

Kock, Luc Allemeersch, Mathieu Boudin \& Philippe Crombé

The origins of Avebury

Mark Gillings, Joshua Pollard \& Kristian Strutt

Mortuary ritual and social identities during the late Dawenkou period in China

Yu Dong, Liugen Lin, Xiaoting Zhu, Fengshi Luan \& Anne P. Underhill

The earliest Bronze Age culture of the south-eastern Gobi Desert, Mongolia Joshua Wright, Galdan Ganbaatar, William Honeychurch, Batdalai

Byambatseren \& Arlene Rosen

Investigating the spatial organisation of Bronze and Iron Age fortress complexes in the South Caucasus

Nathaniel L. Erb-Satullo, Dimitri Jachvliani, Tuna Kalayci, Marine Puturidze \& Katie Simon

The ironworking remains in the royal city of Meroe: new insights on the Nile

Corridor and the Kingdom of Kush

Chris Carey, Frank Stremke \& Jane Humphris

The monastic mosaic at Mount Nebo, Jordan: biogeochemical and epigraphical evidence for diverse origins

Margaret Judd, Lesley Gregoricka \& Debra Foran 
Rethinking the early Viking Age in the West

David Griffiths

Was there mid Holocene habitation in Madagascar? A reconsideration of the

OSL dates from Lakaton'i Anja

Atholl Anderson

The Aberdeen Celt: an early twentieth-century Olmec find

Norman Hammond \& Karl Taube

Demystifying jadeite: an underwater Maya discovery at Ek Way Nal, Belize

Heather McKillop, George Harlow, April Sievert, C. Wayne Smith \& Michael C.

Wiemann

Talking stones: Cherokee syllabary in Manitou Cave, Alabama

Beau Duke Carroll, Alan Cressler, Tom Belt, Julie Reed \& Jan F. Simek

\section{Reviews}

\section{Review article}

Archaeology and the built environment of early medieval England

DUNCAN W. WRIGHT

Building Anglo-Saxon England John Blair

Early medieval Britain: the rebirth of towns in the post-Roman West Pam J. Crabtree

\section{Book reviews}

Ethan E. Cochrane \& Terry L. Hunt The Oxford handbook of prehistoric Oceania

Peter J. Sheppard

Nicky Milner, Chantal Conneller \& Barry Taylor (ed.) Star Carr volume 1: a persistent place in a changing world \& Star Carr volume 2: studies in technology, subsistence and environment

STEPHANIE F. Piper

D. Shane Miller From colonization to domestication: population, environment, and the origins of agriculture in eastern North America

Kristen J. Gremillion

M. Kathryn Brown \& G.J. Bey III (ed.) Pathways to complexity: a view from the Maya lowlands

SARAH E. NEWMAN

Timothy Bruce Mitford East of Asia Minor: Rome's hidden frontier

James CROW

Val Dufeu Fish trade in medieval North Atlantic societies: an interdisciplinary 
Joanne Clarke \& Nick Brooks (ed.) The archaeology of Western Sahara: a synthesis of fieldwork, 2002 to 2009

Maria Carmela Gatto

Eleanor Harrison-Buck \& Julia A. Hendon (ed.) Relational identities and otherthan-human agency in archaeology

Oliver J.T. Harris

Andrew Reinhard Archaeogaming: an introduction to archaeology in and of video games

JUAN HIRIART

Chris Carey, Andy J. Howard, David Knight, Jane Corcoran \& Jen Heathcote (ed.) Deposit modelling and archaeology

Henry Chapman

New Book Chronicle

Claire Nesbitt

\section{Corrigendum}

Review by Vincent Megaw of Andy M. Jones \& Henrietta Quinnell (ed.). An intellectual adventurer in archaeology: reflections on the work of Charles Thomas J.V.S. MEGAW 
Project Gallery on the website (http://www.cambridge.org/core/journals/ antiquity/project-gallery)

H.A.R.P.: investigating Mesolithic landscapes of life and death at the western edge of Europe

Aimée Little, Ben Elliott, Tracy Collins, Edward Blinkhorn, Frank Coyne, Graeme Warren, Gabriel Cooney \& Rick Schulting

Abandonment processes at Middle Bronze Age Erimi: a multi-scalar approach Marialucia Amadio \& Luca Bombardieri

Surveying an Adriatic landscape: non-invasive survey approaches to pre-Roman sites in the ancient Ager Gallicus, Italy

Federica Boschi

Arras 200: revisiting Britain's most famous Iron Age cemetery

Peter Halkon, James Lyall, John Deverell, Tony Hunt \& Manuel Fernández-

Götz

Feeding Anglo-Saxon England: the bioarchaeology of an agricultural revolution Helena Hamerow, Amy Bogaard, Mike Charles, Christopher Ramsey, Richard Thomas, Emily Forster, Matilda Holmes, Mark McKerracher, Samantha Neil \& Elizabeth Stroud

The antiquity of Jaffna Fort: new evidence from post-disaster archaeological investigations in northern Sri Lanka

Christopher Davis, Robin Coningham, Prishanta Gunawardhana,

P. Pushparatnam, Armin Schmidt \& Mark Manuel 